\title{
The role of coconut plants in relation to disaster management in the tropical coastal regions
}

\author{
IGN Anom Rajendra ${ }^{1, *}$, and Dw. Ayu Rai Sumariati ${ }^{2}$ \\ ${ }^{1}$ Department of Architecture, Engineering Faculty, Udayana University, Bali Indonesia \\ ${ }^{2}$ Bali Tourism Institute, Nusa Dua, Indonesia
}

\begin{abstract}
This paper investigates the role of coconut plants growing in the tropical coastal regions in relation to disaster management. The presence of coconut trees on the beach is not solely as a part of landscape architecture but it can also be used as an option in emergency rescue in the occurrence of disaster or tsunami. For this purpose, the investigation was carried out through literature studies and documentation in data collection methods. Video documentation on the attacks of tsunami taking place in some parts of the world were important sources in collecting data. The results of the data collection were then analyzed into qualitative descriptive for verifying the roles of coconut plants in the emergency rescue. Although their roles may not be effective for children, elder and disable people, they are very useful for protection along the coast. The installation of the trees must not only be in public areas but also in private areas along the coast. Since the improvement of disaster management has to cover safety in all aspects, the result of this paper, therefore, may be useful for coastal planning and design guidelines.
\end{abstract}

\section{Introduction}

Coconut as a member of the palm family (Arecaceae), is one of the most economically important trees used by humans. Despite its diverse morphology, coconut is recognized taxonomically as only a single species (Cocos nucifera L.). According to Setyamidjaja [1], there are two major coconut varieties, tall and dwarf, the latter displays traits resulting from selection by humans. The two varieties are not a sensitive species that grows in certain areas; they can grow easily in tropical regions which are able to be found in mountain, hinterland and coastal areas. The coconut palm grows in tens of countries which is an important perennial tropical plantation crop. Meanwhile, Dransfield and Uhl [2] add that it is the sole species of the genus Cocos which contains other economically important species including date palm and oil palm. Moreover, Quang Thien Nguyen, et.al. [3] state that "coconut farming is not only a vital agricultural industry for all tropical countries that possesses humid coasts and lowlands, but is also a robust income provider for millions of smallholder farmers worldwide."

In South East Asia's tropical region, these varieties are one of the most familiar trees since the beginning of the people living in this region. Suhardiyono [4] claims that besides economic reasons, it is also due to useful materials for food, oils, crafts, building materials. Coconut is even used as an important material for rituals in many parts of the region, as a result, it is called 'waste zero' or 'trees of life'. Based on the importance of the coconut, a number of people or farmers choose to plant the coconut in their land; meanwhile, the government has to plant it in some open and public spaces in order to fulfill the needs of industrial sectors. Moreover, the growing of coconut groves in littoral regions seems suitable to exist as giving a sense of eco and natural beauty.

The most important thing to be discussed about the coconut plants in this context is mainly focused on its key role in the safety of human life against sudden big wave, storm/hurricane, even tsunami coming from the sea; whilst some benefits on economic, social and cultural aspects or in enhancing the beauty of coastal regions are to strengthen the main focus. An essential reason to propose and promote coconut plants as an emergency rescue is because the strength of this tree to withstand from the wave attacks. The old coconut plants have vertical and horizontal roots of 8 meters and 16 meters, respectively. Despite the height of up to 15 meters, the trunk is also very strong to withstand from horizontal forces.

When big waves attack the coast, people who are bathing or standing on the coast have an opportunity to save their life by immediately running and then climbing the coconut trees. Although not all people can ride the tree, for instance, children and elder people, every step to provide rescue facilities should be carried out. This is an idea derived from the coconut groves as coastal vegetation that can be utilized as one of the rescue facilities, especially in the coastal regions. The author, however, found a difficulty in collecting data and

Corresponding author: rajendra@unud.ac.id 
information needed for this article. This may have been less attention from some scholars to have a research concerning the role of coconut plants in coastal areas as the emergency rescue. The objective of this article is to propose and ensure that coconut trees are landscape elements that can be applied as an emergency rescue on the coast.

\section{Material and methods}

In order to collect data and analysis for this study, the author collected data and information through literature reviews especially in understanding the characteristics of the coconut tree, and through video, to highlight the important roles in terms of rescue on the shore. From literature reviews, the data, and information that were needed in this study, as follows:

- Characteristics of the coconut trees, comprising taxonomic of hierarchy, a prerequisite of the growth, and its growth in coastal regions;

- General features, describing physical features such as the dimension of the trunk, the length, and depth of the root, as well as its fruit and leaves;

- Benefits of coconut trees growing in coastal regions for people especially in their social and economic aspects; and

- Other possible benefits of planting coconut trees along the coast to avoid unexpected occurrence such as strong wind/storm, big wave/tsunami, and other accidents are the most information needed.

Furthermore, video documentation was used as an essential method for collecting data and information for the study. This method is regarded to represent observation/field survey, since data from video documentations were attempted to come from factual accidents, possibly taking place in tropical coastal regions (for example South East Asia). The evidence from the video documentation such as disaster of storm/tsunami was selected and compiled as the sources of the study.

A number of videos required in the study were unrestricted, meaning that most videos relating to the coastal disaster were collected as much as possible, and they were selected based on criteria. One of the most important criteria to select evidence from videos were humans' efforts to save their life against tsunami attacks. In addition, the presence of the coconut trees when taking place the storm/tsunami also become an important criterion in terms of data collection techniques. The evidence from the videos, therefore, were used as other main sources for the study.

\section{Results and discussion}

This section is systematically divided into two subsections as results and discussion. The results of the study are some data collection presented in figures and tables, whilst the discussion is to analyze the result of the study into a descriptive analysis.

\subsection{Results}

Due to a part of data derived from online video documentation, data collected on the video consisted of some images explaining situation and condition of coastal surroundings; for example some accidents describing the situation during tsunami on the coasts. To ensure a validity of the data and information or to avoid misleading tsunami concept, most images mainly derived from www.youtube.com which were selected carefully based on actual events.

An important accident collected in this study are tsunami attacks taking place on $26^{\text {th }}$ December 2004 in the Indian Ocean which was only $15-20 \mathrm{~km}$ from the coast of Aceh (South West of Sumatra Island) part of Indonesia territory. One of the most tremendous tsunami attacks in the $21^{\text {st }}$ century. Most people in the world knew this accident, hence the videos of this accident would have a guarantee on the truth of the video documentation. Results of the study are able to be classified into two parts; description of the coconut trees on the coast and tremendous accidents (tsunami attacks) on the coasts

\subsubsection{Characteristics of coconut plants in tropical coastal regions.}

Coconut has grown in tens of countries which the coconut (Cocos nucifera L.) is an important perennial tropical plantation crop [5]. It occurs in the palm family (Arecaceae) and is the sole species of the genus Cocos within the subfamily Arecoideae which also contains other economically important species including date palm and oil palm [4]. Prasanthi Perera, et al. [6] add that it is a cross-pollinating palm, propagated only by seeds, whilst tissue culture is the only vegetative propagation method available for coconut. According to the description of the coconut tree, it has many names based on its taxonomic hierarchy as shown below (Table 1).

Meanwhile, according to Abdurachman and Mulyani [7], coconut plants have conditions to grow and develop optimally on deep fraction soil conditions with a $\mathrm{pH}$ of $5.5-8$. Salinity and sandy soil supported by abundant sunlight and regular rainfall (1,500-2,500 mm annually) are more suitable for coconut plants to thrive. In addition, Da Cunha [8] argues that the plants require warm conditions with high humidity between $70-80 \%$, whereas they are not fit to thrive in cold weather and low humidity. From this point of view, the coconut can thrive optimally in South East Asia Regions due to climate and weather reasons. In fact, according to Chan [9], Indonesia and Philippine at South East Asia's tropical regions are the largest producer of the coconut trees in the world. Meanwhile, Sarwono Hardjowigeno [10] in his research added that the plants will thrive well in low land and near the shore. This approves that the trees are fit to plant on the tropical coastal regions. 
Table. 1. Taxonomic Hierarchy of Coconut Tree

\begin{tabular}{|c|c|c|}
\hline \multicolumn{3}{|c|}{ Taxonomic Hierarchy } \\
\hline Kingdom & Plantae & - Plants \\
\hline Subkingdom & Viridiplantae & \\
\hline Infrakingdom & Stretophyta & - Land plants \\
\hline Superdivision & Embryophyta & \\
\hline Division & Traceaphyta & - Vascular plants \\
\hline Subdivision & Spermatophytina & - $\quad$ Seed plants \\
\hline Class & Magnoliopsida & \\
\hline Superorder & Lilianae & \\
\hline Order & Arecaceae & \\
\hline Family & Areceae & \\
\hline Genus & $\operatorname{Cocos} \mathrm{L}$ & - Coconut palm \\
\hline Species & Cocos nucifera L. & Coconut palm \\
\hline
\end{tabular}

Source: https://www.itis.gov/servlet/SingleRpt

\subsubsection{General physical features}

The anatomical features of coconut tree were observed relating to its stem, root, crown leaves. Nany Sudarna [11] states that the stem from several heights and depths have a diameter of 22 to $30.5 \mathrm{~cm}$ and the heights of 15 to $30 \mathrm{~m}$ above the soil base. The stem height from a tall coconut can reach $30 \mathrm{~m}$, whilst the height of a dwarf coconut has not more than $15 \mathrm{~m}$ above the soil base. Meanwhile, the coconut has strong roots which are supported by the width and depth of the root to the soil, even its root can be seen above the soil. The wide root can reach 10-15 $\mathrm{m}$ wide (a radius of 7.5 m), and 3.5- $8 \mathrm{~m}$ deep (see Fig. 1). The crown leaves are up to $15 \mathrm{~m}$ both sides. Rudi Hartawan and Arif Sarjono [12] add that since the texture of the coconut from its root, stem to the leaves made of fiber, all parts of the coconut have a high strength which is very strong to withstand from strong wind, big waves, and other horizontal attacks as shown in Fig. 1.

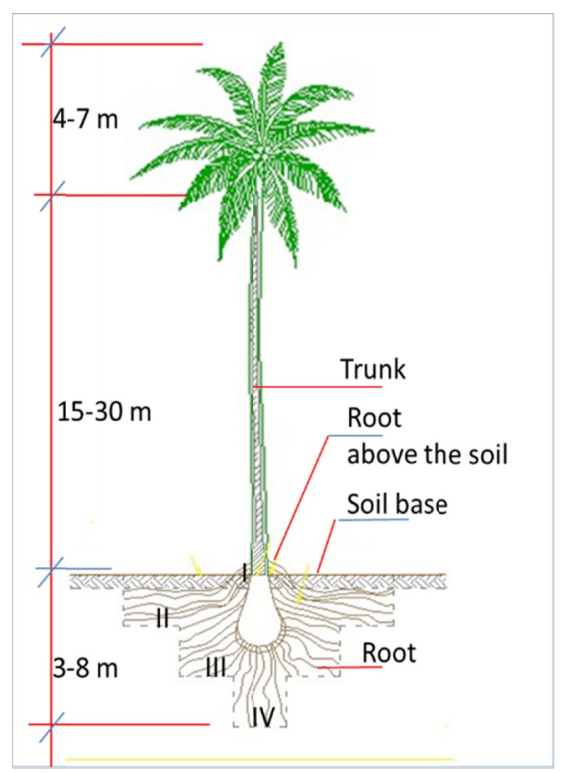

Fig. 1. Schematic Diagram of the Coconut Tree

\subsubsection{The presence of the coconut trees facing tsunami attacks}

Data collection from online video documentation that constitutes factual accidents took place in South East Regions a couple years ago. The tremendous accidents derived from tsunami attacks taking place in $26^{\text {th }}$ December 2004 in which the source of cause was at around 15-20 km from the coast of Aceh or South West of Sumatra Island in Indonesia, preceded by earth quack with the strength of up to 9 Richter scale. These attacks did not only destroy the coast of Aceh but also parts of the regions such as Thailand and Sri Lanka, whilst the victims in Aceh were estimated at more than 200 thousand died. During the worst accidents from the attacks, however, there was some evidence appeared in the videos concerning the presence of the coconut trees whereby the trees still survived and safely stood (Fig. 2\&3), even the post attacks (Fig. 8 \& 9). It seems a higher risk for humans without trees on the coast (Fig. 4). Meanwhile, people who during the attacks attempted to climb and used coconut trees to keep their life (Fig. 5, 6\&7). From these images, the coconut trees were clearly used by some people to save their life, and coconut trees have proven to be used as an opportunity to save humans during the tsunami attacks as shown in Fig. 2,3,4,5,6,7,8, and 9.

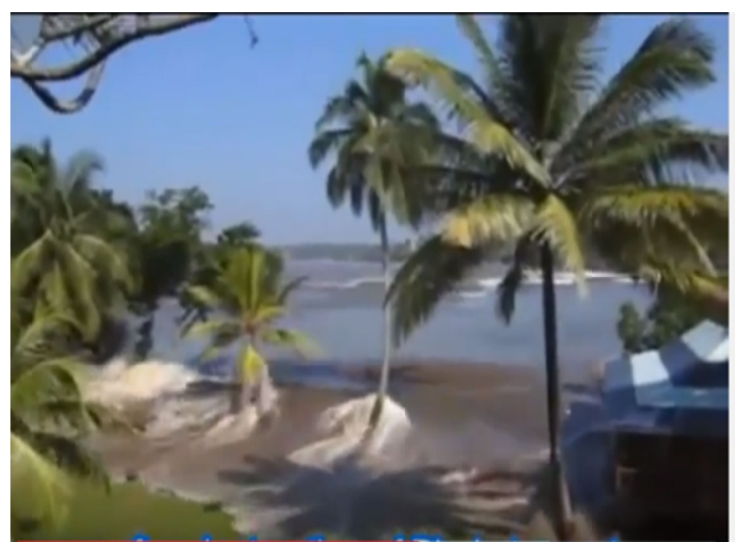

Fig. 2. The Presence of the Coconut during Tsunami Attacks. Source: www.youtube.com

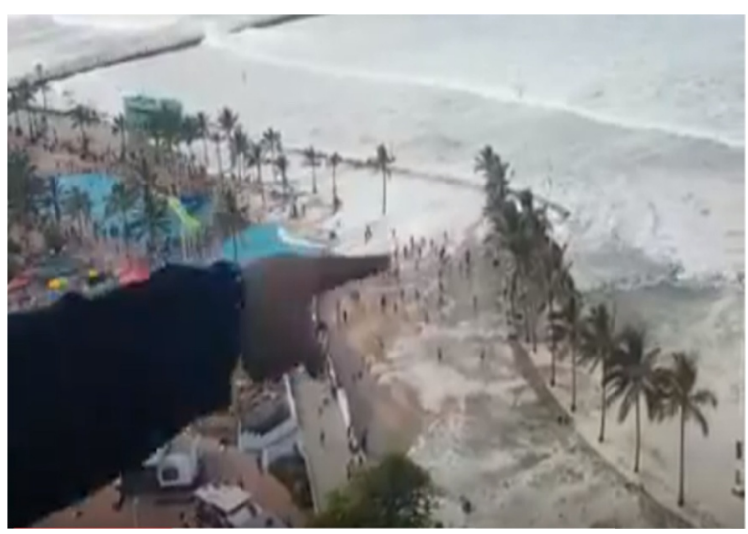

Fig. 3. The coconut along with the Shoreline in Facing the Tremendous Attack. Source: www.youtube.com 


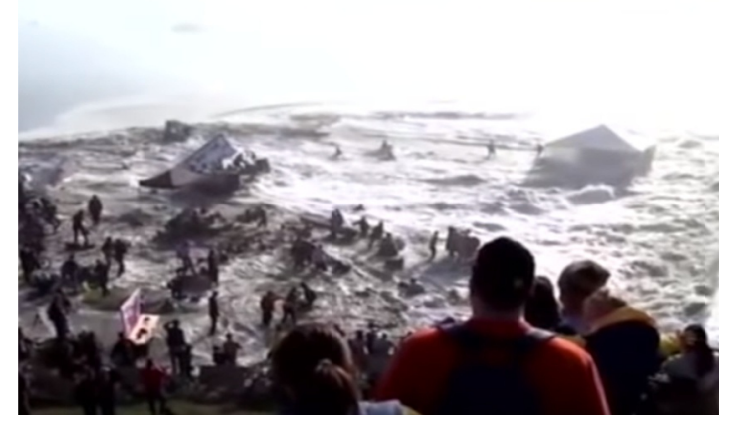

Fig. 4. High Risk for Humans on the Coast without Coconut Trees. Source: www.youtube.com

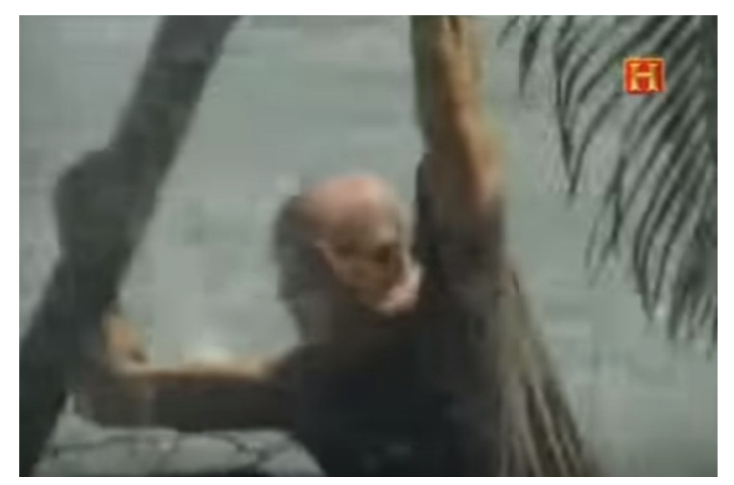

Fig. 5. A Man Attempted to Hold a Coconut Tree to Keep His Life. Source: www.youtube.com

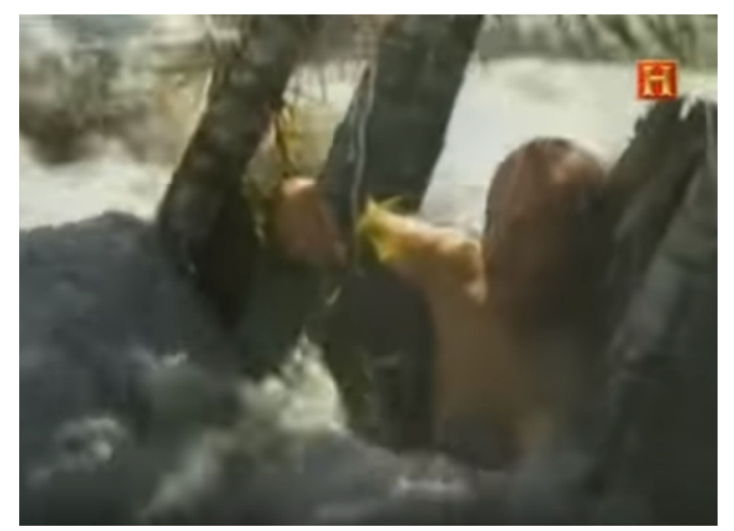

Fig. 6. Coconut Trees Protected a Man from Tsunami Attack. Source: www.youtube.com

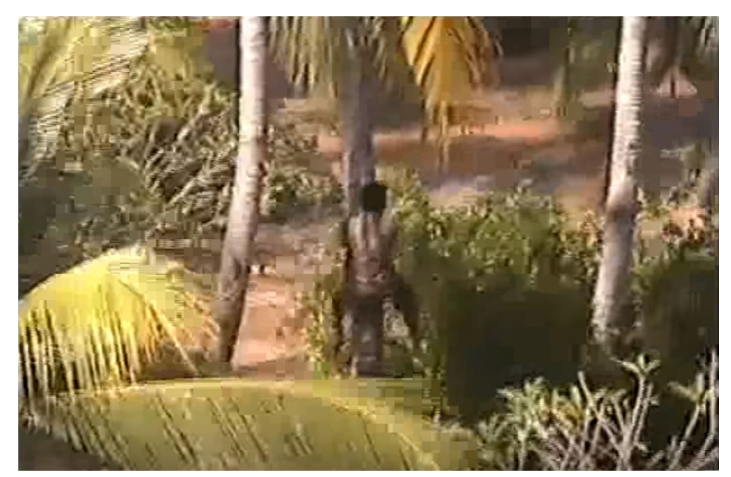

Fig. 7. A Man made an effort to Climb Coconut Tree. Source: www.youtube.com

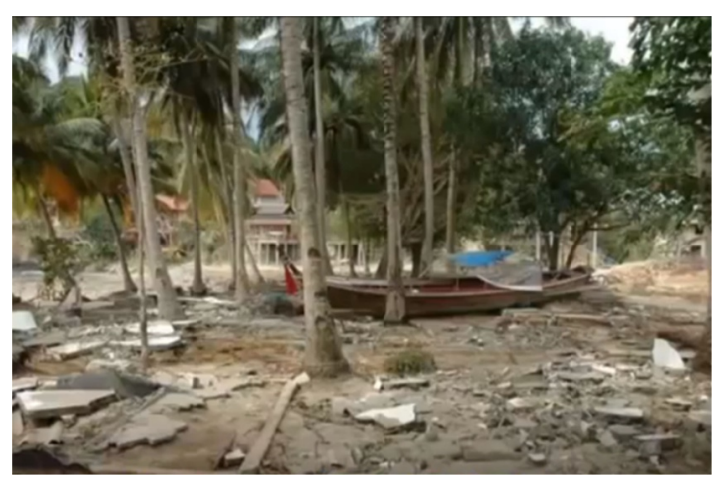

Fig. 8. Coastal surroundings after Tsunami. Source: www.youtube.com

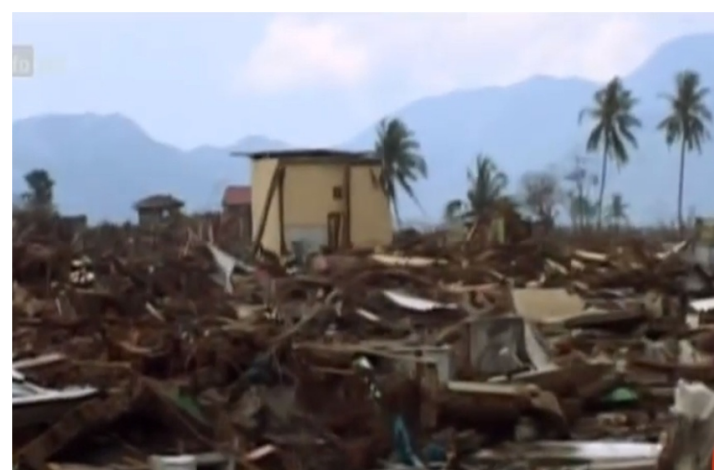

Fig. 9. Coconut Trees Appeared to Keep Standing. Source: www.youtube.com

\subsection{Discussion}

According to the results, the discussion on the role of the coconut trees as an emergency rescue in facing big waves/tsunami and other functions can be divided into three parts that are:

\subsubsection{The strength of the coconut trees to withstand against big waves/tsunami}

From considerable evidence, especially from video documentation, the coconut trees has proven that they were very strong to face the strong winds, big waves, and tsunami attacks particularly taking place in the tropical coastal regions, although the impacts of the attacks may have resulted in devastating pest and disease outbreaks of the coconut trees [3]. Possibly, the initial plan of the coconut trees' installations could not aim to test their strength. Besides their root, the strength of their trunk also helps them to stand firmly when hit by the storm/tsunami attacks.

\subsubsection{The opportunity of the coconut trees in tropical coastal regions as media in emergency rescue}

During storms or tsunami, every medium for safety our life is immediately required since the attacks are very fast to occur. Open spaces on the coast are very wide, whilst we need enough time to run in finding a safe place. If we are bathing or swimming near the shoreline, 
it will be difficult to save our lives when coming storm very fast attacking the coast. An opportunity to safe our life, in that case, is to climb immediately a tree near the shore. In order to easily climb the tree, some notches at the trunks of the coconut should be made from the base (Fig. 10.).

Based on the evidence, the coconut trees growing along the coast are the most opportunity to be used in order to save our lives. Even though it not effective for all people especially for children and elder people, every opportunity to save our life from the attacks of natural disaster should be available. It means that the coconut plants do not only offer some benefits in social, cultural, and economic aspects but also an important benefit in an emergency rescue. As a consequence, the planting of coconut trees particularly in tropical coastal regions become an important strategy in relation to disaster mitigation and management, and it will be started from the planning and design stages as shown in Fig. 10 .

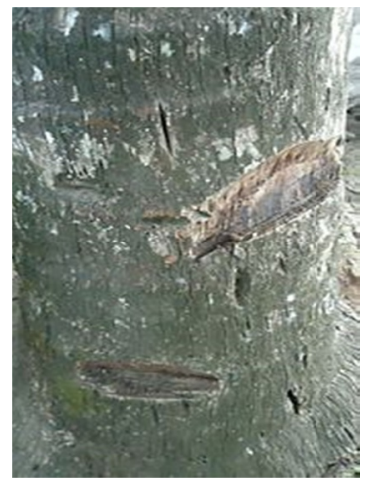

Fig. 10. Notches from Base to Top Should be Available to Facilitate Humans Climbing. Source: www.youtbe.com

\subsubsection{A concept of installation of ihe coconut rees in public and private coastal areas (tourist beach resorts)}

It may be difficult to install coconut trees in public and private spaces if not supported by planning and design strategies. In order to fulfill the objective of coconut planting along the coasts, it can be approached through the implementation of government laws. Indonesia country, for instance, coastal open spaces (non-built areas) called setback line, according to Indonesia National Law [13], is measured by $100 \mathrm{~m}$ from High Water Level/HWL to onshore; it means that these spaces are fully used for public only. Hence, there are wide spaces to plant the coconut trees. The installation of the trees is arranged to form 'a line' along the shore which is able to be used as a boundary line. To avoid straight line in an array of the coconut, a wavy line following the characteristics of the shoreline can also be created (Fig. 11). This boundary, then, can be used as a benchmark to control and monitor the law enforcement on the beach/coast, whilst the coastal landscape will be more natural and beautiful.

Furthermore, planting the coconut in private spaces such as tourist beach resorts, it can be approved by providing an agreement of understanding among stakeholders who are responsible to maintain coastal areas as a whole. For public interests and disaster management, the local government can insist on private landowners to install coconut trees in their areas in terms of fulfilling planning and design guidelines. Therefore, the coastal environment completed by landscape elements of coconut trees can be adopted into an integrated coastal planning and design leading to benefits to all as shown in Fig. 11,12, and 13.

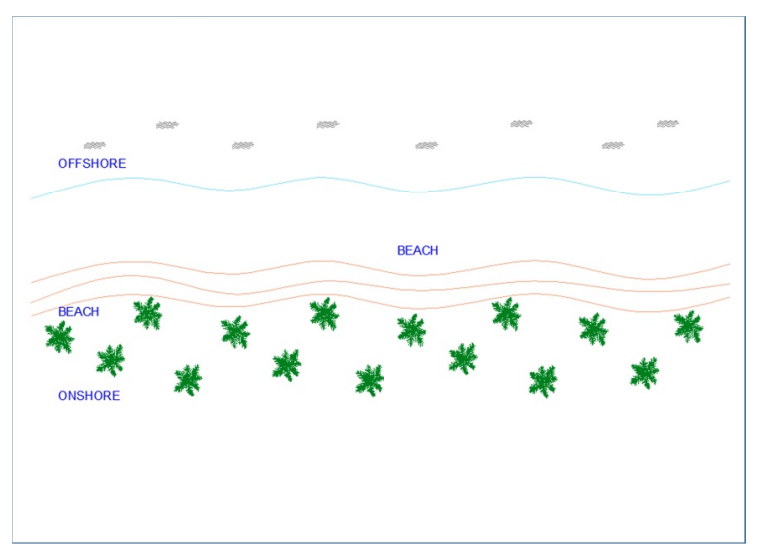

Fig. 11. A Concept of Coconut Tree's Installation Following Characteristics of Coastlines

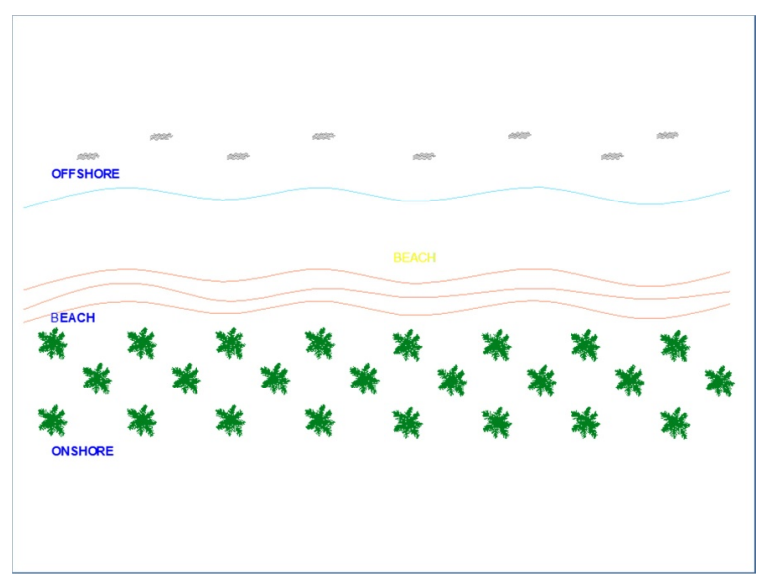

Fig. 12. A Concept of Installation Using Straight Line to the Shoreline in Order to Control Setback Line

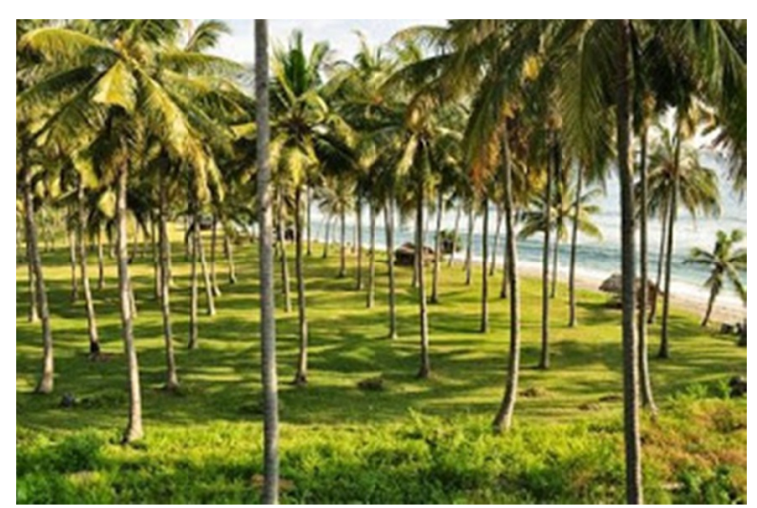

Fig. 13. Coconut Groves near the Coast Look Beautiful and Natural. Source: www.google.com 


\section{Conclusion}

From the discussion, some conclusions may be inferred as follows:

- Contextual information revealed in the study is that the coconut trees are an important coastal plant since they have a wide range of functions in the coastal regions; one of those is able to be used for emergency purposes, i.e.: rescue from strong wind/storm, big wave/tsunami. Although the installation of the coconut trees may not be effective for emergency rescue during the tsunami, a little opportunity available must be carried out in the context of disaster management and mitigation.

- The utilization and application of the coconut tree as an emergency rescue is likely a new idea even though it reveals to require some considerations on the field in order to ensure the usefulness. Social and cultural actions in the use of the coconut trees for the rescue of human life, however, are necessary to be done besides great economic benefits.

- The role of the local government as policymakers should be encouraged to socialize the planting of the coconut trees along the coast which is not only in public spaces but is also planted in private areas. As a result, the presence of these trees in the tropical coastal regions will be the need of emergency rescue and an identity driving to have a natural sense of the coasts.

\section{References}

1. Setyamidjaja, D. (1991). Oil Palm Cultivation. Kanisius.

2. Dransfield, J., and N. W. Uhl. "An Outline of a Classification of Palms Principes 30. 03-11." (1986).

3. Nguyen, Quang Thien, et al. "Biology, propagation and utilization of elite coconut varieties (makapuno and aromatics)." Plant Physiology and Biochemistry 109 (2016): 579-589.

4. Suhardiyono, L. (1991). Tanaman kelapa: budidaya dan pemanfaatannya. Kanisius.

5. Novarianto, Hengky, et al. "Embryo maturity plays an important role for the successful cryopreservation of coconut (Cocos nucifera)." In Vitro Cellular \& Developmental BiologyPlant 50.6 (2014): 688-695

6. Perera, Prasanthi IP, et al. "Effect of plant growth regulators on ovary culture of coconut (Cocos nucifera L.)." Plant Cell, Tissue and Organ Culture (PCTOC) 99.1 (2009): 73-81.

7. Abdurachman dan Mulyani. 2003. Kesesuaian lahan tanaman kelapa. [Online]. Available: http://www.anakagronomy.com/2013/04/analisiskesesuaian-lahan-untukanaman.html

8. Da Cunha, Maura, et al. "Fine structure of phloematic trypanosomatid-coconut tree interaction." Journal of general plant pathology 76.1 (2010): 74-83.
9. Chan, Edward, and Craig R. Elevitch. "Cocos nucifera (coconut)." Species profiles for Pacific Island agroforestry 2 (2006): 1-27.

10. 10. Hardjowigeno, Sarwono. Land Suitability Evaluation and Design of Land Use. Gadjah Mada University Press, 2007.

11. 11. Sudarna, Nenny S. "Anatomy of a coconut stem (Cocos nucifera L.)." Journal of Forest Products Research 7.3 (1990): 111-117.

12. Hartawan, Rudi and Arif Sarjono. "Physical Characteristics and Production of Deep Coconut (Cocos nucifera L) in Various Land Ecology." Jurnal Pertanian Pertanian 1.2 (2016): 45-54.

13. Indonesia, PRESIDENT OF THE REPUBLIC. "Republic of Indonesia Law Number 26 of 2007 concerning Spatial Planning." State Gazette of the Republic of Indonesia Year (2007). 